\title{
Consideration of hazardous and especially hazardous hydrometeorological impacts in design of buildings and structures of nuclear power plants
}

\author{
Fedor Bryukhan ${ }^{1, *}$ \\ ${ }^{1}$ Moscow State University of Civil Engineering, Department of Engineering Survey and Geoecology, \\ Yaroslavskoe sh 26, 129337 Moscow, Russia
}

\begin{abstract}
External impacts of the hydrometeorological origin have a significant influence on the safety level of objects of use of atomic energy (OUAE), including nuclear power plants (NPP). Therefore, the existing NPP-related safety regulations demand to consider such impacts at all stages of the NPP life cycle. It is important to make decisions on considering or ignoring certain external impacts while designing NPP buildings and structures. The main criterion for such decisions is the probability of a non-project accident associated with the release of radionuclides into the environment when an extreme phenomena occurs. The aim of this study is to develop a concept for refinement regulatory requirements, considering hydrometeorological factors in organization of NPP engineering protection. Criteria for consideration of hazardous and especially hazardous hydrometeorological impacts for design of NPP buildings and structures were analyzed, and recommendations for refinement of regulatory requirements, considering hydrometeorological factors in organization of NPP engineering protection, were developed.
\end{abstract}

\section{Introduction}

External impacts of the hydrometeorological origin have a significant influence on the safety level of nuclear facilities, including NPP [1, 2]. International and Russian OUAE safety codes and regulations state that such impacts shall be considered at all stages of their life cycle [3, 4].

These codes and regulations generally require to consider a wide range of hydrological and meteorological phenomena and processes. However, they do not provide clear criteria determining the need for consideration of relevant hydrological and meteorological loads in calculations. So it is necessary to refine regulatory requirements for consideration of hydrometeorological factors in provision of NPP engineering protection.

\footnotetext{
* Corresponding author: pniiis-gip@mail.ru
} 


\section{Hydrological and meteorological phenomena and processes}

The abovementioned normative technical documents $[3,4]$ require consideration of external hydrometeorological factors listed in Table 1, which also indicates general impacts of such factors on NPP buildings and structures.

Table 1. External hydrometeorological factors and their general impacts.

\begin{tabular}{|c|c|}
\hline Factors & General impacts \\
\hline Flood & $\begin{array}{l}\text { Flooding of the NPP site, dynamic } \\
\text { impacts on buildings, structures, } \\
\text { utilities, foundation subsidence }\end{array}$ \\
\hline Tsunami & $\begin{array}{l}\text { Flooding of the NPP site, dynamic } \\
\text { impacts of tsunami waves on buildings, } \\
\text { structures, foundation subsidence, } \\
\text { temporary fall in water level within the } \\
\text { coastal area }\end{array}$ \\
\hline $\begin{array}{l}\text { Ice phenomena on water } \\
\text { courses (ice jams, gorges) }\end{array}$ & $\begin{array}{l}\text { Flooding of coastal territories due to } \\
\text { water rise in water courses, dynamic } \\
\text { impacts on hydraulic engineering } \\
\text { structures }\end{array}$ \\
\hline $\begin{array}{l}\text { Coastal wave conditions } \\
\text { (run-down, run-up, hurricane } \\
\text { wave) }\end{array}$ & $\begin{array}{l}\text { Flooding of the NPP site, dynamic } \\
\text { impacts on buildings, structures, } \\
\text { utilities, corrosion effects }\end{array}$ \\
\hline Seiche & $\begin{array}{l}\text { Flooding of coastal territories, } \\
\text { temporary fall in water level in water } \\
\text { bodies }\end{array}$ \\
\hline Tidal surges and ebbs & $\begin{array}{l}\text { Intermittent flooding of coastal } \\
\text { territories, fall in water level within the } \\
\text { coastal area }\end{array}$ \\
\hline $\begin{array}{l}\text { Changes in water resources } \\
\text { (extremely low water yield, } \\
\text { abnormal fall in water level) }\end{array}$ & $\begin{array}{l}\text { Shortage of water for NPP cooling } \\
\text { systems }\end{array}$ \\
\hline Tornado & $\begin{array}{l}\text { Dynamic impacts of tornado air flow } \\
\text { and pressure drop on buildings and } \\
\text { structures, impacts from flying objects }\end{array}$ \\
\hline Tropical cyclone (typhoon) & $\begin{array}{l}\text { Wind loads on buildings and structures, } \\
\text { stormwater loads on roofs of buildings } \\
\text { and structures, hail impacts, flooding of } \\
\text { the NPP site }\end{array}$ \\
\hline Extreme wind & Wind loads on buildings and structures \\
\hline Extreme precipitation & $\begin{array}{l}\text { Stormwater loads on roofs of buildings } \\
\text { and structures, hail impacts }\end{array}$ \\
\hline $\begin{array}{l}\text { Extreme snowfalls and snow } \\
\text { cover }\end{array}$ & $\begin{array}{l}\text { Static loads on roofs of buildings and } \\
\text { structures }\end{array}$ \\
\hline Extreme air temperature & $\begin{array}{l}\text { Temperature loads on members of } \\
\text { buildings and structures, impacts on } \\
\text { communication lines }\end{array}$ \\
\hline
\end{tabular}


Table 1 (continuation).

\begin{tabular}{|l|l|}
\hline \multicolumn{1}{|c|}{ Factors } & \multicolumn{1}{c|}{ General impacts } \\
\hline Snow avalanche & $\begin{array}{l}\text { Shock action, the NPP site buried under } \\
\text { snow }\end{array}$ \\
\hline Glaze ice & $\begin{array}{l}\text { Ice loads on wires, wire vibration, } \\
\text { kinking, swinging }\end{array}$ \\
\hline Lightning discharge & $\begin{array}{l}\text { Failure of networks, equipment, fire } \\
\text { hazard, injurious action on the NPP } \\
\text { personnel }\end{array}$ \\
\hline
\end{tabular}

According to the table, potential impacts of the listed factors are quite diverse. However, the mentioned extreme hydrometeorological phenomena and processes can cause a non-project NPP accident only in extremely rare occasions. Taking into account the importance of NPP radiation safety assurance, even such cases require detail analysis of possible consequences of a hypothetical accident.

\section{Probabilistic safety criteria for NPP}

Decision on consideration or ignoring of certain hydrometeorological factors according to [4] shall be based on the threshold probability $P_{0}$ (basically, recurrence), which is $10^{-4} /$ year per reactor. However, taking into account high dangers of tornados and their impacts on NPPs, their threshold probability is assumed equal to $10^{-7} /$ year per reactor $[5,6]$. Lightning impacts on NPP buildings, structures and infrastructure also have specific features. In many instances, parameters of their impacts considered by design shall be determined at the expert level.

Collection and analysis of input data for statistical processing and determination of design hydrometeorological characteristics are carried in the process of engineering hydrometeorological surveys [7]. Statistical data processing is performed using standard methods (e. g., refer to [8, 9]).

In Russia and other IAEA member counties, NPP safety requirements are based on nonexceedance of the non-project accident probability with the accidental release limit of $P_{G}=$ $10^{-7} /$ year [4]. This value is the main criterion of NPP safety in relation to external impacts of different origin.

The non-project accident probability caused by a specific hydrometeorological factor is

$$
P=P_{0} \times P_{A}
$$

where $P_{A}$ - dimensionless probability of an accident resulting in maximum permissible release into the environment upon occurrence of the impact event for this factor. With $P_{A}=$ 1 for tornado impacts and $P_{A}>10^{-3}$ for impacts of other hydrometeorological factors, the non-project accident probability will reach or exceed the main safety criteria of $P_{G}=10^{-}$ $7 /$ year. In case of tornado impacts the non-project accident with radionuclides release is not always inevitable. This is due to the fact that according to the tornado zoning scheme of the ex-USSR territory the estimated characteristics of the maximum probable tornado with the NPP impact probability of $10^{-7} /$ year can be relatively weak $[5,6,10]$.

As for impacts of other hydrometeorological factors, their consideration shall be formally based not on the occurrence of the threshold probability of $P_{0}=10^{-4} /$ year, as it is provided for by federal regulations [4], but on the following condition: 


$$
P_{0} \times P_{A}>P_{G}
$$

To ensure appropriate NPP protection against external impacts, including those of the hydrometeorological origin, engineering measures shall be implemented for NPP protection.

If the threshold probability of $P_{0}=10^{-4} /$ year is still considered, the NPP engineering protection is required, when the non-project accident probability resulting from the impact of a specific hydrometeorological factor $P_{A}$ exceeds $10^{-3}$. In its turn, the maximum estimated value of a relevant hydrological or meteorological factor, e.g. water level or wind speed, is the probability level quantile of $1-10^{-4} /$ year and is determined basing on the statistical distribution of this value. In addition, this greatly varying quantile will by no means always result in a non-project accident with a probability above $10^{-3}$. Otherwise stated, the potential hazard from the impact of such meteorological factor can be overestimated and cause excessive material costs for NPP engineering protection.

To avoid this, it is necessary to proceed not from the assumption of the threshold level of $P_{0}=10^{-4} /$ year, but from the following condition:

$$
P_{0}\left(x_{C}\right) \times P_{A}\left(x_{C}\right)=P_{G}
$$

In this formula $x_{C}$ is the estimated extreme value of the variable $x$ (probability level quantile of $1-P_{0} \times$ year). Dependence of the non-project accident probability $P_{A}\left(x_{C}\right)$ on the impact of a given hydrological or meteorological factor $x$ is derived from construction calculations. The cumulative distribution function $1-P_{0}(x) \times$ year of the variable concerned is determined based on results of statistical processing of observation data. Therefore, it is generally not difficult to determine values of $x_{C}, P_{0}$ and $P_{A}$. It may turn out that the quotation (3) will have no solution, if the variation range of the hydrological or meteorological variable $x$ does not result in a potential non-project accident with a probability above $10^{-3}$. This means that in some cases the danger of occurrence of a certain hydrological or meteorological event may be overestimated.

The engineering protection of NPPs from hydrometeorological factors provides for significant expenditures for new construction of each object as well as for its expansion or reconstruction. In some cases there will not be necessary to design expensive protection from some factors without reduction of the NPPs safety.

In this regard, it seems advisable to refine regulatory requirements to consideration of hydrometeorological factors, as well as other factors of the natural origin in designing a NPP.

\section{Conclusions}

- Based on the applicable NPP safety codes and regulations, analysis of consideration criteria for hazardous and especially hazardous hydrometeorological impacts in NPP design.

- Recommendations for refinement of regulatory requirements were developed to consider hydrometeorological factors in organization of NPP engineering protection against such factors.

- It is noted that there may be situations when there is no need to design the engineering protection from some factors without reduction of the NPP safety.

The author thanks Dr A.Yu. Vinogradov, Director General of the Scientific \& Industrial Association Gidrotekhproekt for useful consultations. 


\section{References}

1. I.V. Kaliberda, Evaluation of the parameters of external actions of natural and technogenic origin: Safety of the objects of use of atomic energy (Logos Publishing House, Moscow, 2002)

2. A.N. Birbraer, A.Yu. Roleder, Extreme actions on structures (St. Petersburg Polytechnic University Publishing House, St. Petersburg, 2009)

3. Meteorological and hydrological hazards in site evaluation for nuclear installations: Specific safety guide. IAEA safety standards. No SSG-18 (IAEA Publishing House, Vienna, 2011)

4. NP-064-05. Taking into account of actions of natural and technogenic origin on nuclear power plants (Rostekhnadzor Publishing House, Moscow, 2005)

5. F.F. Bryukhan, A.D. Potapov, Atomic Energy 115, 346-350 (2014)

6. RB-022-01, Vestnik Gosatomnadzora Rossii 1, 59-90 (2002)

7. SP 11-103-97. Engineering and hydrometeorological surveys for construction. (Gosstroy of Russia Publishing House, Moscow, 1997)

8. V.N. Malinin. Statistical methods for the analysis of hydrometeorological information (Russian State Hydrometeorological University Publishing House, St. Petersburg, 2008)

9. D.S. Wilks, Statistical Methods in the atmospheric sciences. 2-nd ed (Academic Press, New York, 2002)

10. F.F. Bryukhan, A.D. Potapov, Bulletin of the Moscow State Regional University, series «Natural sciences» 4, 48-51 (2014) 